\title{
MEKANISME PENGUJIAN SPP DAN PENERBITAN SPM DI BALAI BESAR WILAYAH SUNGAI BENGAWAN SOLO
}

\author{
LMS. Kristiyanti
}

Akademi Akuntansi Surakarta

\begin{abstract}
Abstrak
Pertanggungjawaban pengelolaan keuangaan Negara merupakan wujud transparansi dan akuntabilitas. Pengelolaaan keuangan negara merupakan penyampaian laporan pertanggungjawaban keuangan pemerintah yang memenuhi prinsip-prinsip tepat waktu, disusun mengikuti standar akuntansi pemerintah yang telah diterima umum. Balai Besar Wilayah Sungai Bengawan Solo merupakan unit pelaksanaan teknis dibidang konservasi sumber daya air, pengembangan sumber daya air, pendayagunaan sumber daya air dan pengendalian daya rusak air pada wilayah sungai Bengawan Solo, bertanggungjawab kepada Direktur Jenderal Sumber Daya Air. Tata cara pembayaran dalam rangka pelaksanaan Anggaran Pendapatan dan Belanja Negara (APBN) mencakup beberapa bagian seperti tertulis dalam Peraturan Menteri Keuangan Republik Indonesia Nomer 190/PMK 05/2012. Mekanisme pengujian SPP dan Penerbitan SPM di Balai Besar Wilayah Sungai Bengawan Solo, berdasar pada Peraturan Menteri Keuangan Republik Indonesia Nomor 190/PMK.05/2012 tentang: Tata Cara Pembayaran Dalam Rangka Pelaksanaan Anggaran Pendapatan Dan Belanja Negara pasal 56, 57, 58 dan 59.
\end{abstract}

Kata kunci: APBN, pengujian SPP, penerbitan SPM. 


\section{PENDAHULUAN.}

Untuk memberikan informasi mengenai perkembangan pelaksanaan APBN / APBD, pemerintah pusat / pemerintah daerah perlu menyampaikan laporan realisasi semester pertama kepada DPR / DPRD pada akhir Juli tahun anggaran yang bersangkutan. Informasi yang disampaikan dalam laporan tersebut menjadi bahan evaluasi pelaksanaan APBN / APBD semester pertama dan penyesuaian/perubahan APBN / APBD pada semester berikutnya.

Ketentuan mengenai pengelolaan keuangan negara APBN / APBD ditetapkan tersendiri dalam undang-undang yang mengatur perbendaharaan negara mengingat lebih banyak menyangkut hubungan administratif antar kementrian Negara / lembaga di lingkungan pemerintah.

Pertanggungjawaban pengelolaan keuangaan negara, salah satu upaya konkrit untuk mewujudkan transparansi dan akuntabilitas. Pengelolaaan keuangan negara adalah penyampaian laporan pertanggungjawaban keuangan pemerintah yang memenuhi prinsipprinsip tepat waktu dan disusun dengan mengikuti standar akuntansi pemerintah yang telah diterima secara umum. Dalam undangundang ini ditetapkan bahwa laporan pertanggungjawaban pelaksanaan APBN / APBD disampaikan berupa laporan keuangan yang setidak-tidaknya terdiri dari laporan realisasi anggaran, neraca, laporan arus kas, dan catatan atas laporan keuangan yang disusun sesuai dengan standar akuntansi pemerintah.

Laporan keuangan pemerintah pusat yang telah diperiksa oleh Badan Pemeriksa Keuangan harus disampaikan kepada DPR selambat-lambatnya 6 (enam) bulan setelah berakhirnya tahun anggaran yang bersangkutan, demikianpula laporan keuangan pemerintah daerah yang telah diperiksa oleh Badan Pemeriksa Keuangan harus disampaikan kepada DPRD selambatlambatnya 6 (enam) bulan setelah berakhirnya tahun anggaran yang bersangkutan

Balai Besar Wilayah Sungai Bengawan Solo merupakan unit pelaksanaan teknis dibidang konservasi sumber daya air, pengembangan sumber daya air, pendayagunaan sumber daya air dan pengendalian daya rusak air pada wilayah sungai Bengawan Solo dan bertanggungjawab kepada Direktur Jenderal Sumber Daya Air.

Tata cara pembayaran Dalam Rangka Pelaksanaan Anggaran Pendapatan dan Belanja Negara atau disingkat dengan (APBN) mencakup beberapa bagian seperti yang sudah tertulis dalam Peraturan Menteri Keuangan Republik Indonesia Nomer 190/PMK 05/2012 Bagian penguji SPP (Surat Perintah Pembayaran) dan Penerbitan SPM (Surat Perintah Membayar) dan diperiksa oleh bagian PPSPM (Pejabat Penandatangan Surat Perintah Membayar) yang kemudian disampaikan oleh PPK (Pejabat Pembuat Komitmen).

Makalah ini akan membahas mekanisme pengujian SPP dan penerbitan SPM di Balai Besar Wilayah Sungai Bengawan Solo.

\section{PEMBAHASAN}

\section{Keuangan Negara}

Keuangan Negara adalah seluruh kekayaan negara dalam bentuk apapun, yang dipisahkan atau yang tidak dipisahkan, termasuk didalamnya segala bagian kekayaan negara dan segala hak dan kewajiban yang ditimbulkan karena:

a. Berada dalam penguasaan, pengurusan, dan pertanggungjawaban pejabat lembaga negara, baik ditingkat pusat maupun didaerah. 
b. Berada dalam penguasaan, pengurusan, dan pertangggungjawaban Badan Usaha Milik Negara/Badan Usaha Milik Daerah, yayasan, badan hukum dan perusahaan yang menyertakan modal negara, atau perusahaan yang menyertakan modal negara pihak ketiga berdasarkan perjanjian dengan negara.

Bidang pengelolaan keuangan Negara yang demikian luas dapat dikelompokkan dalam sub bidang pengelolaan fiskal, sub bidang pengelolaan moneter,dan sub bidang pengelolaan kekayaan negara yang dipisahkan.

2. Asas-asas umum pengelolaan Keuangan Negara

Dalam rangka mendukung terwujudnya good governance dalam penyelenggaraan negara, pengelolaan keuangan negara perlu diselenggarakan secara profesional, terbuka, dan bertanggungjawab sesuai dengan aturan pokok yang telah ditetapkan dalam undangundang dasar. Berikut ini kaidah-kaidah yang baik dalam pengelolaan keuangan negara, antara lain:

a. Akuntabilitas berorientasi pada hasil

b. Profesionalitas

c. Proposionalitas

d. Keterbukaan dalam pengelolaan keuangan negara

e. Pemeriksaan keuangan oleh badan pemeriksa yang bebas dan mandiri.

3. Kekuasaan atas Pengelolaan Keuangan Negara.

Presiden selaku Kepala Pemerintahan memegang kekuasaan pengelolaan keuangan negara sebagai bagian dari kekuasaan pemerintahan. Kekuasaan tersebut meliputi kewenangan yang bersifat umum dan kewenangan yang bersifat khusus. Untuk membantu presiden dalam penyelenggaraan kekuasaan dimaksud, sebagian dari kekuasaan tersebut dikuasakan kepada Menteri keuangan selaku Pengelolaan Fiskal dan wakil Pemerintah dalam kepemilikan kekayaan negara yang dipisahkan, serta kepada Menteri/ Pimpinan Lembaga selaku Pengguna Anggaran/ Pengguna Barang Kementrian negara/ Lembaga yang dipimpinnya.

\section{Penetapan APBN.}

Anggaran adalah alat akuntabilias manajemen, dan kebijakan ekonomi sebagai instrumen kebijakan ekonomi anggaran berfungsi untuk mewujudkan pertumbuhan dan stabilitas serta pemerataan pendapatan dalam rangka mencapai tujuan bernegara. Dalam upaya untuk meluruskan kembali tujuan DPR/DPRD dan pemerintah dalam proses penyusunan dan penetapan anggaran sebagai penjabaran aturan pokok yang telah ditetapkan dalam undangundang dasar 1945. Anggaran belanja pemerintah dikelompokkan atas anggaran belanja rutin dan anggaran belanja pembangunan.

\section{Pelaksanaan APBN}

Setelah APBN ditetapkan secara rinci dengan undang-undang,pelaksanaannya dituangkan lebih lanjut dengan keputusan presiden sebagai pedoman bagi kementrian negara/lembaga dalam pelaksanaan anggaran

6. Pertanggungjawaban Pengelolaan Keuangan Negara

Upaya konkrit untuk mewujudkan transparansi dan akuntabilitas pengelolaan keuangan negara adalah penyampaian laporan pertanggungjawaban keuangan pemerintah yang memenuhi prinsip-prinsip tepat waktu dan disusun dengan mengikuti standar akuntansi pemeritah yang telah diterima secara umum. Dalam undang-undang ditetapkan bahwa laporan 
pertanggungjawaban pelaksanaa APBN/ APBD disampaikan berupa laporan keuangan yang terdiri dari laporan realisasi anggaran, neraca, laporan arus kas dan catatan atas laporan keuangan yang disusun sesuai dengan standar akuntansi pemerintah.

Laporan keuangan pemerintah pusat yang telah diperiksa oleh Badan Pemeriksa Keuangan harus disampaikan kepada DPR selambat-lambatnya 6 (enam) bulan setelah berakhirnya tahun anggaran yang bersangkutan,demikian pula laporan keuangan pemerintah daerah yang telah diperiksa oleh Badan Pemeriksa Keuangan harus disampaikan kepada DPRD selambatlambatnya 6 (enam) bulan setelah berakhirnya tahun anggaran yang bersangkutan.

\section{Balai Besar Wilayah Sungai Bengawan Solo.}

Balai Besar Wilayah Sungai Bengawan Solo beralamat di jalan Solo Kartasura Km.7 Pabelan, Surakarta. Instansi ini merupakan unit pelaksanaan teknis dibidang konservasi sumber daya air, pengembangan sumber daya air pada wilayah sungai Bengawan Solo dan bertanggungjawab kepada Direktur Jenderal Sumber Daya Air. Berdasarkan Peraturan Menteri Pekerjaan Umum Nomor: 21/PRT/M/2010 tentang Organisasi dan Tata Kerja Unit Pelaksanaan Teknis Kementrian Pekerjaan Umum berikut ini adalah tugas dan fungsi BBWS Bengawan Solo.

a. Tugas

Melaksanakan pengelolaan sumber daya air diwilayah Sungai Bengawan Solo yang meliputi perencanaan, pelaksanaan kontruksi, operasi, dan pemeliharaan dalam rangka konservasi dan pendayagunaan sumber daya air dan pengendalian daya rusak air pada sungai, danau, waduk, bendungan dan tampungan air lainnya, irigrasi, air tanah, air baku, rawa, tambak dan pantai.

b. Fungsi

1) Pengelolaan sistem informasi sumber daya air

2) Penyusunan rencana dan pelaksanaan pengelolaan kawasan lindung sumber air pada wilayah sungai Bengawan Solo

3) Pelaksanaan urusan tata usaha dan rumah tangga balai serta koordinasi dengan instansi terkait.

4) Pemberdayaan masyarakat dalam pengelolaan sumber daya air.

5) Pengelolaan sistem hidrologi

6) Pengendalian dan pengawasan kontruksi pelakasanaan pembangunan sumber daya air.

7) Penyusunan pola dan rencana pengelolaan sumber daya air pada wilayah sungai Bengawan Solo.

c. Strukur Organisasi Struktural.

1) Bagian tata usaha

Tugas memberikan pelayanan administratif kepada semua unsur dilingkungan BBWS Bengawan Solo dan kooordinasi dengan instansi terkait

2) Bidang Program dan Perencanaan Umum Tugas melaksanakan penyusunan pola dan rencana pengelolaan sumber daya air, rencana pengelolaan kawasan lindung sumber air pada wilayah sungai.

3) Bidang Pelaksanaan Jaringan Sumber Air Tugas: Melaksanakan konservasi sumber daya air, pengendalian daya rusak air dan pengendalian sedimen

4) Bidang Pelaksanaan Jaringan Pemanfaatan Air

Fungsi:

a) Pelaksanaan perencanaan teknis sarana dan prasarana irigrasi, rawa, tambak, air baku dan air tanah. 
b) Penyusunan rencana persiapan operasi dan pemeliharaan sarana dan prasarana irigrasi, rawa, ambak, air baku, dan air tanah.

c) Pengendalian dan pengawasan pelaksanaan kontruksi sarana dan prasarana irigrasi, rawa, ambak, air baku dan air tanah

5) Bidang Operasi dan Pemeliharaan

Fungsi:

a) Perencanaan, Pengendalian dan Pengawasan pelaksanaan operasi dan pemeliharaan sarana dan prasarana sumber daya air.

b) Pelaksanaan pengelolaan kawasan lindung sumber air pada wilayah sungai.

c) Pelaksanaan penerapan sistem manajemen mutu dalam penyelenggaraan operasi dan pemeliharaan

6) Kelompok Jabatan Fungsional

Tugas: Melakukan kegiatan sesuai dengan jabatan fungsional masing-masing berdasarkan peraturan perundangundangan

d. Jabatan non structural

1. Satker Balai Besar Wilayah Sungai Bengawan Solo

a. Kepala Satker Balai Besar Wilayah Sungai Bengawan Solo

Tugas:

1) Melaksanakan seluruh tugas satuan kerja pusat terutama pelaksanaan rencana kerja yang telah ditetapkan dan dituangkan dalam Daftar Isian Pelaksanaan Anggaran (DIPA).

2) Memimpin pelaksanaan seluruh rencana kerja yang telah ditetapkan dan dituangkan dalam DIPA.

3) Menetapkan Panitia/Pejabat Pengadaan Barang dan Jasa.

Tanggungjawab:
1) Bertanggungjawab atas seluruh pelaksanaan kegiatan/rencana kerja yang tertuang dalam DIPA.

2) Bertanggungjawab atas semua penerimaan/pengeluaran satuan kerja yang membebani APBN.

3) Bertanggungjawab terhadap realisasi keuangan dan pencapaian keluaran/output yang telah ditetapkan.

4) Bertanggungjawab terhadap penatausahaan dan pemeliharaan Barang Milik/ kekayaan Negara satuan kerja

b. Bendahara Pengeluaran

Tugas:

1) Menyelenggarakan pembukuan seluruh transaksi keuangan yang dilaksanakan satuan kerja BBWS Bengawan Solo pada Buku Kas Umum (BKU), Buku Pembantu, Buku tambahan, serta Bukubuku tambahan lainnya.

2) Menandatangani Surat Permintaan Pembayaran Uang Persediaan (SPP-UP) yang diajukan oleh Pejabat Pembuat Komitmen dan selanjutnya menyampaikannya kepada pejabat yang melakukan pengujian dan perintah pembayaran.

3) Menandatangani SPP-LS yang pembayarannya melalui rekening bendahara.

Tanggungjawab:

1) Bertanggungjawab atas pengelolaan uang persediaan Satker Balai Besar WilayaSungai Bengawan Solo.

2) Bertanggungjawab kepada kepala Satuan Kerja.

c. Pejabat Penerbit SPM

Tugas:

1) Menerima berkas SPP yang disampaikan oleh Pejabat Pembuat Komitmen.

2) Memeriksa kelengkapan berkas SPP, mengisi checklist kelengkapan berkas SPP 
dan mencatat dalam buku pengawasan penerimaan SPP.

3) Memeriksa secara rinci keabsahan dokumen pendukung SPP sesuai dengan ketentuan dan peraturan perundangundangan yang berlaku.

Tanggungjawab :

1) Bertanggungjawab secara administraif terhadap hasil pengujian meliputi aspek hukum, peraturan perundang-undangan dan tujuan pengeluaran.

2) Bertanggungjawab kepada Kepala Satuan Kerja.

d. Pelaksanaan Anggaran pada Satuan Kerja Balai Besar Wilayah Sungai Bengawan Solo tahun anggaran 2012 terdiri atas :

1) Pejabat Pembuat Komitmen (PPK) ketatalaksanaan.

2) PPK Pengelolaan Barang Milik Negara.

3) PPK Perencanaan dan Program.

4) PPK O \& P. Sumber Daya Air I

5) PPK O \& P. Sumber Daya Air II

6) PPK O \& P. Sumber Daya Air III

2. SNVT Pelaksanaan Jaringan Sumber Air Bengawan Solo.

a. Kepala SNVT Pelaksanaan Jaringan Sumber Air Bengawan Solo.

Tugas: Melaksanakan pengelolaan sumber daya air yang meliputi konservasi sumber daya air, pendayagunaan sumber daya air dan pengendalian daya rusak air pada wilayah sungai Bengawan Solo.

b. Bendahara Pengeluaran

Tugas:

1) Menyelenggarakan pembukuan seluruh transaksi keuangan yang dilaksanakan SNVT Pelaksanaan Jaringan Sumber Air Bengawan Solo pada Buku Kas Umum (BKU), Buku Pembantu, Buku Tambahan, serta Buku-buku Tambahan lainnya.
2) Menandatangani Surat Permintaan Pembayaran Uang Persediaan (SPP-UP) yang diajukan oleh Pejabat Pembuat Komitmen dan selanjutnya menyampaikan kepada pejabat yang melakukan Pengujian dan Perintah Membayar.

3) Menandatangani SPP-LS yang Pembayarannya melalui Rekening Bendahara.

Tanggungjawab:

1) Bertanggungjawab atas pengelolaan uang persediaan SNVT pelaksanaan Jaringan Sumber Air Bengawan Solo.

2) Bertanggungjawab kepada Kepala Satuan Kerja.

c. Pejabat Penerbit SPM

Tugas:

1) Menerima berkas SPP yang disampaikan oleh Pejabat Pembuat Komitmen,

2) Membuat SPM untuk dikirim ke KPPN Surakarta untuk proses pencairan dana.

3) Memeriksa kelengkapan berkas SPP, mengisi check list kelengkapan berkas SPP dan mencatat dalam buku pengawasan penerimaan SPP.

4) Menyelenggarakan tata cara kearsipan yang bersangkutan dengan bukti-bukti asli pembayaran.

Tanggungjawab:

1) Bertanggungjawab secara administratif terhadap hasil pengujian meliputi aspek hukum, peraturan perundang-undangan dan tujuan pengeluaran.

2) Bertanggungjawab kepada kepala satuan kerja.

d. Pelaksanaan Anggaran pada SNVT Pelaksanaan Jaringan Sumber Air Bengawan Solo berdiri tahun anggaran 2012 terdiri atas:

1) PPK Sungai dan Pantai I

2) PPK Sungai dan Pantai II 
3) PPK Sungai dan Pantai III

4) PPK Prasarana Konservasi Sumber Daya Air I

5) PPK Prasarana Konservasi Sumber Daya Air II

3. SNVT Pelaksanaan Jaringan Pemanfaatan Air Bengawan Solo

a. Kepala SNVT Pelaksanaan Jaringan Pemanfaatan Air Bengawan Solo

Tugas: Melaksanakan pengelolaan sumber daya air yang meliputi pendayaan sumber daya air dan pengendalian daya rusak air pada wilayah sungai Bengawan Solo.

b. Bendahara Pengeluaran

Tugas:

1) Menyelenggarakan pembukuan seluruh transaksi keuangan yang dilaksanakan SNVT pelaksanaan jaringan pemanfaatan Air Bengawan Solo pada Buku Kas umum (BKU), Buku Pembantu, Buku Tambahan, serta Buku-buku tambahan lainnya.

2) Menandatangani Surat Permintaan Pembayaran Uang Persediaan (SPP-UP) yang diajukan oleh Pejabat Pembuat Komitmen dan selanjutnya menyampaikannya kepada Pejabat yang melakukan pengujian dan perintah pembayaran.

3) Menandatangani SPP-LS yang pembayarannya melalui Rekening Bendahara.

Tanggungjawab:

1) Bertanggungjawab atas pengelolaan uang persediaan SNVT pelaksanaan Jaringan Pemanfaatan Air Bengawan Solo.

2) Bertanggungjawab kepada Kepala Satuan Kerja.

c. Pejabat Penerbit SPM

Tugas:

1) Menerima berkas SPP yang disampaikan oleh Pejabat Pembuat Komitmen.
2) Memeriksa kelengkapan berkas SPP, mengisi check list kelengkapan berkas SPP dan mencatat dalam buku pengawasan penerimaan SPP.

3) Memeriksa secara rinci keabsahan dokumen pendukung SPP sesuai dengan ketentuan dan peraturan perundangundangan yang berlaku.

4) Menyelenggarakan tata kearsipan yang bersangkutan dengan bukti-bukti asli pembayaran.

Tanggungjawab:

1) Bertangggungjawab secara administratif terhadap hasil pengujian meliputi aspek hukum, peraturan perundang-undangan dan tujuan pengeluaran.

2) Bertanggungjawab kepada kepala satuan kerja.

d. Pelaksanaan Anggaran pada SNVT pelaksanaan Jaringan Pemanfaatan Air Bengawan Solo tahun anggaran 2012 terdiri atas:

1) PPK Pengembangan Air Baku

2) PPK Pendayagunaan Air Tanah

3) PPK Irigrasi \& Rawa I

4) PPK Irigrasi \& Rawa II

8. Mekanisme Pengujian SPP.

Menurut Peraturan Menteri Keuangan Republik Indonesia Nomor 190/PMK.05/2012 tentang: TATA CARA PEMBAYARAN DALAM RANGKA PELAKSANAAN ANGGARAN PENDAPATAN DAN BELANJA NEGARA.

Pasal 56 menyatakan:

1) PPSPM melakukan pemeriksaan dan pengujian SPP beserta dokumen pendukung yang disampaikan oleh PPK,

2) Pemeriksaan dan pengujian SPP beserta dokumen pendukung SPP sebagaimana dimaksud pada ayat (1), meliputi : 
a. Pengujian sebagaimana dimaksud dalam pasal 17 ayat (3), dan

b. Keabsahan dokumen pendukung sebagaimana dimaksud dalam pasal 40 ayat (2) dan ayat (3).

3) Dalam hal pemeriksaan dan pengujian SPP beserta dokumen pendukungnya sebagaimana dimaksud pada ayat (2) memenuhi ketentuan, PPSPM menerbitkan/menandatangani SPM.

4) Jangka waku pengujian SPP sampai dengan penerbitan SPM-UP/TUP/GUP/P TUP/LS oleh PPSPM diatur sebagai berikut :

a) Untuk SPP-UP/TUP diselesaikan paling lambat 2 (dua) hari kerja.

b) Untuk SPP-GUP diselesaikan paling lambat 4 (empat) hari kerja.

c) Untuk SPP-PTUP diselesaikan paling lambat 3 (tiga) hari kerja dan

d) Untuk SPP-LS diselesaikan paling lambat 5 (lima) hari kerja.

5) Dalam hal PPSPM menolak/mengembalikan SPP karena dokumen pendukung tagihan tidak lengkap dan benar, maka PPSPM harus menyatakan secara tertulis alasan penolakan/pengembalian tersebut paling lambat 2 (dua) hari kerja setelah diterimanya SPP.

Pasal 57 menyatakan:

1) Seluruh bukti pengeluaran sebagai dasar pengujian dan penerbitan SPM disimpan oleh PPSPM.

2) Bukti pengeluaran sebagaimana dimaksud pada ayat (1) menjadi bahan pemeriksaan bagi aparat pemeriksa internal dan eksternal.

9. Mekanisme Penerbitan SPM

Menurut Peraturan Menteri Keuangan Republik Indonesia Nomor 190/PMK.05/2012 tentang: Tata Cara
Pembayaran Dalam Rangka Pelaksanaan Anggaran Pendapatan Dan Belanja Negara. Pasal 58 menyatakan:

1) Penerbitan SPM oleh PPSPM sebagaimana dimaksud dalam pasal 56 ayat (3) dilakukan melalui sistem aplikasi yang disediakan oleh Derektorat Jenderal Perbendaharaan.

2) SPM yang diterbitkan melalui sistem aplikasi SPM sebagaimana dimaksud pada ayat (1) memuat Personal Identification Number (PIN), PPSPM sebagi tanda tangan elektronik pada ADK SPM dari penerbit SPM yang sah.

3) SPM sebagai dimaksud pada ayat (1) dibuat sesuai fomat sebagaimana tercontoh dalam lampiran XIII yang merupakan bagian tidak terpisahkan dari Peraturan Menteri ini.

4) Dalam penerbitan SPM melalui sistem aplikasi sebagaimana dimaksud pada ayat (1), PPSPM bertanggungjawab atas :

a) Keamanan data pada aplikasi SPM.

b) Kebenaran SPM dan kesesuaian antara data pada SPM dengan data pada ADK SPM, dan

c) Penggunaan Personal identification Number (PIN) pada ADK SPM

Pasal 59 menyatakan:

1) PPSPM menyampaikan SPMUP/TUP/GUP/GUP-Nihil/PTUP/LS dalam rangkap 2 (dua) beserta ADK SPM kepada KPPN.

2) Menyampaikan SPM-UP/SPMTUP/SPM-LS sebagaimana dimaksud pada ayat (1) diatas sebagai berikut :

a) Penyampaian SPM-UP dilampiri dengan surat pernyataan dari KPA yang dibuat sesuai format sebagaimana tercantum dalam lampiran XIV yang merupakan bagian tidak terpisahkan dari Peraturan Menteri ini. 
b) Penyampaian SPM- TUP dilampiri dengan Surat Setoran Pajak (SSP) dan/atau buku setor lainnya, dan/atau daftar nominatif untuk yang lebih dari (1) penerima.

3) Khusus untuk penyampaian SPM-LS dalam rangka pembayaran jaminan uang muka atas perjanjian/kontrak, juga dilampiri dengan :

a) Asli Surat Jaminan uang muka.

b) Asli Sura Kuasa bermaterai cukup dari PPK kepada Kepala KPPN untuk mencairkan jaminan uang muka, dan

c) Asli konfimasi tertulis dari pimpinan penerbit jaminan uang muka sesuai peraturan presiden mengenai pengadaan barang/jasa pemerintah.

4) Khusus untuk penyampaian SPM atas beban pinjaman/hibah luar negeri, juga dilampiri dengan faktur pajak.

5) PPSPM menyampaikan SPM kepada KPPN paling lambat 2 (dua) hari kerja setelah SPM diterbitkan.

6) SPM-LS untuk pembayaran gaji induk disampaikan kepada KPPN paling lambat tanggal 15 sebelum bulan pembayaran.

7) Dalam hal tanggal 15 sebagaimana dimaksud pada ayat (6) merupakan hari libur, penyampaian SPM-LS untuk pembayaran gaji induk kepada KPPN dilakukan paling lambat 1 (satu) hari kerja sebelum tanggal 15 .

8) Pelaksanaan ketentuan sebagaimana dimaksud pada ayat (7) dikecualikan untuk Satker yang kondisi geografis dan transportasinya sulit, dengan memperhitungkan waktu yang dapat dipertanggungjawabkan.

9) Penyampaian SPM kepada KPPN dilakukan oleh petugas pengantar SPM yang sah dan ditetapkan oleh KPA dengan ketentuan sebagai berikut : a) Petugas pengantar SPM harus menunjukkan Kartu Identitas Petugas Satker (KIPS) pada saat penyampaian SPM kepada petugas front office.

b) Petugas pengantar SPM menyampaiakan SPM beserta dokumen pendukung dan ADK SPM melalui front office penerimaan SPM pada KPPN.

c) Dalam hal SPM tidak dapat disampaikan secara langsung ke KPPN, penyampaian SPM beserta dokumen pendukung dan ADK SPM dapat melalui kantor pos/jasa pengirim resmi.

10) Penyampaian SPM melalui kantor pos/jasa pengiriman resmi sebagaimana dimaksud pada ayat (9) huruf c, KPA terlebih dahulu menyampaikan konfirmasi/pemberitahuan kepada kepala KPP. 


\section{SIMPULAN}

Balai Besar Wilayah Sungai Bengawan Solo merupakan unit pelaksanaan teknis dibidang konservasi sumber daya air, pengembangan sumber daya air, pendayagunaan sumber daya air dan pengendalian daya rusak air pada wilayah sungai Bengawan Solo dan bertanggungjawab kepada Direktur Jenderal Sumber Daya Air.

Mekanisme pengujian SPP dan Penerbitan SPM di Balai Besar Wilayah Sungai Bengawan Solo, berdasar pada Peraturan Menteri Keuangan Republik Indonesia Nomor 190/PMK.05/2012 tentang: Tata Cara Pembayaran Dalam Rangka Pelaksanaan Anggaran Pendapatan Dan Belanja Negara pasal 56, 57, 58 dan 59.

Pengujian SPP yang benar dokumen pendukung tagihan harus lengkap oleh PPSPM dan seluruh bukti pengeluaran sebagai dasar pengujian dan penerbitan SPM disimpan oleh PPSPM.

Penerbitan SPM yang dikerjakan melalui sistem aplikasi yang telah disediakan oleh Direktorat Jenderal Perbendaharaan. Penyampaian SPM kepada KPPN dilakukan oleh petugas pengantar SPM yang sah dan ditetapkan oleh KPA. Untuk penyampaian SPM melalui kantor pos/jasa pengiriman resmi, KPA terlebih dahulu menyampaikan konfirmasi/pemberitahuan kepada kepala KPPN.

Pengujian SPP dan Penerbitan SPM melibatkan bagian PPK, SPM, KPPN, dan Bendahara Pengeluaran. 


\section{DAFTAR PUSTAKA}

Mahmudi, 2007, Manajemen Kinerja Sektor Publik, Edisi kedua, STIM YKPN, Yogyakarta.

Nordiawan, Deddi et al., 2008, Akuntansi Pemerintahan, Salemba Empat, Jakarta.

Payamta, 2013, Materi Kuliah Sistem Akuntansi Pemerintahan, FE UNS, Surakarta.

Peraturan Menteri Keuangan Republik Indonesia Nomor 190/PMK.05/2012 tentang Tata Cara Pembayaran Dalam Rangka Pelaksanaan Anggaran Pendapatan Dan Belanja Negara.

Peraturan Menteri Pekerjaan Umum Nomor 21/PRT/M/2010 tentang Organisasi dan Tata Kerja Unit Pelaksanaan Teknis Kementrian Pekerjaan Umum. 